\title{
Dysregulated Editing of Serotonin 2C Receptor mRNAs Results in Energy Dissipation and Loss of Fat Mass
}

\author{
Yukio Kawahara, ${ }^{1}$ Adda Grimberg, ${ }^{2}$ Sarah Teegarden, ${ }^{3}$ Cedric Mombereau, ${ }^{4}$ Sui Liu, ${ }^{1}$ Tracy L. Bale, ${ }^{3}$ Julie A. Blendy, ${ }^{4}$ \\ and Kazuko Nishikura ${ }^{1}$ \\ ${ }^{1}$ The Wistar Institute, ${ }^{2}$ Department of Pediatric Endocrinology, The Children's Hospital of Philadelphia, Abramson Research Center, ${ }^{3}$ Department of \\ Animal Biology, University of Pennsylvania, and ${ }^{4}$ Department of Pharmacology, University of Pennsylvania School of Medicine, Philadelphia, Pennsylvania \\ 19104
}

RNA editing that converts adenosine to inosine replaces the gene-encoded Ile, Asn, and Ile (INI) of serotonin [5-hydroxytryptamine (5-HT) ] receptor $2 \mathrm{C}\left(5-\mathrm{HT}_{2 \mathrm{C}} \mathrm{R}\right)$ with Val, Gly, and Val (VGV). Up to 24 different $5-\mathrm{HT}_{2 \mathrm{C}} \mathrm{R}$ isoforms are detected in different brain regions (Burns et al., 1997; Fitzgerald et al., 1999; Wang et al., 2000). To elucidate the physiological significance of 5- $H T_{2 C} R$ mRNA editing, we derived mutant mouse lines harboring a knock-in INI or $V G V$ allele, resulting in sole expression of one of two extremely different editing isoforms 5- $\mathrm{HT}_{2 \mathrm{C}} \mathrm{R}$-INI (editing blocked) or -VGV (fully edited). Although INI mice grew normally, VGV mice had a severely reduced fat mass, despite compensatory hyperphagia, as a result of constitutive activation of the sympathetic nervous system and increased energy expenditure. Furthermore, serotonergic neurotransmission was oversensitized in VGV mice, most likely because of the increased cell surface expression of VGV receptors. Melanocortin 4 receptor (MC4R) regulates energy homeostasis (Balthasar et al., 2005; Heisler et al., 2006; Lam et al., 2008), and $M c 4 r^{-1-}$ mice are obese because of hyperphagia and reduced energy expenditure (Huszar et al., 1997). However, the elevated energy expenditure of $V G V$ mice could not be rescued in the $M c 4 r^{-I-}$ background, indicating the presence of a distinct signaling pathway mediated via $5-\mathrm{HT}_{2 \mathrm{C}} \mathrm{R}-\mathrm{VGV}$ that dominates the MC4R-dependent pathway in control of energy expenditure. Our results highlight the importance of regulated $5-H T_{2 C} R$ mRNA editing, because dysregulation could result in the pathological consequences such as growth retardation seen in $V G V$ mice.

Key words: RNA editing; ADAR; serotonin receptor 2C; energy homeostasis; melanocortin 4C receptor; obesity

\section{Introduction}

One type of RNA editing involves the conversion of adenosine residues into inosine $(\mathrm{A} \rightarrow \mathrm{I}$ RNA editing) in double-stranded RNA (dsRNA) through the action of adenosine deaminases acting on RNA (ADAR) (Bass, 2000; Nishikura, 2006). Because the translation machinery reads inosines as if they were guanosines, when it occurs within the coding sequence, RNA editing could result in the synthesis of proteins not directly encoded by the genome. $\mathrm{A} \rightarrow \mathrm{I}$ RNA editing is involved in alterations of neurotransmitter receptor and channel functions (Reenan, 2001; Greger et al., 2002; Seeburg and Hartner, 2003; Ohlson et al., 2007; Rula et al., 2008) as well as modulation of microRNA expression levels and target selection (Yang et al., 2006; Kawahara et al., 2007a,b, 2008).

Serotonin [5-hydroxytryptamine $(5-\mathrm{HT})]$ receptor $2 \mathrm{C}$ (5-

Received Aug. 4, 2008; revised 0ct. 3, 2008; accepted 0ct. 21, 2008.

This work was supported by grants from the National Institutes of Health (A.G., T.L.B., J.A.B., K.N.), the Juvenile Diabetes Research Foundation (K.N.), and the Commonwealth Universal Research Enhancement Program, Pennsylvania Department of Health (K.N). We thank B. B. Lowell and J. K. Elmquist for LoxTB:Mc4r mice; R. B. Emeson for sharing unpublished results; J. M. Murray, A. Weber, and H. J. Grill for reading and comments; J. Richa for generation of chimeric mice; H. Collins for measurement of serum hormones; R. Dhir for energy expenditure analysis; and J. T. Lee for preparation of targeting constructs.

Correspondence should be addressed to Dr. Kazuko Nishikura, The Wistar Institute, 3601 Spruce Street, Philadelphia, PA 19104. E-mail: kazuko@wistar.org.

DOI:10.1523/JNEUROSCI.3896-08.2008

Copyright $\odot 2008$ Society for Neuroscience $\quad$ 0270-6474/08/2812834-11\$15.00/0
$\mathrm{HT}_{2 \mathrm{C}} \mathrm{R}$ ) is detected exclusively in the CNS and plays roles in various physiological and behavioral processes. Increased anxiety (Heisler et al., 2002), hyperlocomotion (Nonogaki et al., 2003), and adult-onset hyperphagia and obesity (Tecott et al., 1995) have been reported with $5-H T_{2 C} R$-null mice, confirming the importance of $5-\mathrm{HT}_{2 \mathrm{C}} \mathrm{R}$ in the regulation of emotion, locomotion, and appetite and metabolic rate control. A $\rightarrow$ I RNA editing occurs at five sites (A, B, C, D, and E sites) located in exon 5 of 5- $H T_{2 C} R$ pre-mRNAs (see Fig. $1 A$ ) (Burns et al., 1997). Combinatorial editing at the five sites would change three amino acids I156, N158, and I160 (INI) located at the intracellular II region consisting of the G-protein coupling domain of the receptor (Burns et al., 1997; Fitzgerald et al., 1999; Wang et al., 2000). An imperfect dsRNA structure consisting of exon 5 and the downstream intron 5 sequence of $5-H T_{2 C} R$ pre-mRNA is essential for editing (see Fig. 1A) (Burns et al., 1997; Wang et al., 2000). Previous studies conducted in vitro in transfected non-neuronal cells indicated that RNA editing may modulate receptor functions such as 5-HT potency, agonist binding affinity, constitutive activities, and types of $\mathrm{G}_{\alpha}$ subunits to be coupled. The fully edited VGV isoform receptor exhibited the most prominent alterations in G-protein coupling functions compared with the completely unedited INI receptor (Burns et al., 1997; Fitzgerald et al., 1999; Niswender et al., 1999; Wang et al., 2000). Furthermore, RNA editing changes the cell surface expression of the $5-\mathrm{HT}_{2 \mathrm{C}} \mathrm{R}$ by 
affecting the intracellular trafficking efficacy (Marion et al., 2004).

To evaluate the significance of $5-H T_{2 C} R$ mRNA editing in vivo, the development of mutant mouse lines harboring a knock-in allele that results in sole expression of a single $5-\mathrm{HT}_{2 \mathrm{C}} \mathrm{R}$ isoform is needed. Here, we derived two mutant mouse lines that resulted in sole expression of two extremely different editing isoforms, one editing blocked (INI) and the other fully edited (VGV). Phenotypic analysis of these mouse lines, INI and VGV, revealed the importance of the tight control of the $5-H T_{2 C} R$ mRNA editing, because overediting of $5-H T_{2 C} R$ mRNAs, represented in $V G V$ mice, results in oversensitization of serotonergic neurotransmission and inappropriately elevated energy expenditure, and consequent growth retardation and reduced fat mass accumulation.

\section{Materials and Methods}

Mice. Mice were maintained on a $12 \mathrm{~h}$ light/dark cycle at a temperature of $22 \pm 1{ }^{\circ} \mathrm{C}$ with a humidity of $60-70 \%$. All procedures involving mice were approved by the Institutional Care and Use Committee of the Wistar Institute and performed in accordance with the National Institutes of Health guidelines.

Generation of VGV and INI mice. Inosine is interpreted as guanosine by the translational machinery. In the $5-H T_{2 C} R-V G V$ knock-in vector, five $\mathrm{A} \rightarrow \mathrm{G}$ mutations at sites $\mathrm{A}-\mathrm{E}$ were introduced, whereas the editing complementary sequence in intron $5(160 \mathrm{bp})$ was deleted in the $5-\mathrm{HT}_{2 \mathrm{C}} R$ $I N I$ targeting vector (see Fig. $1 \mathrm{~A}$ ). A silent $\mathrm{XbaI}$ site created upstream of the editing sites in exon 5 facilitated screening of the mutated allele in ES cells and knock-in mice (see Fig. 1B). ES cell clones selected for G418 resistance and ganciclovir sensitivity were screened by Southern hybridization analysis using three probes specific for the $5^{\prime}$ and $3^{\prime}$ regions of the $5-H T_{2 C} R$ gene and the Neo gene (see Fig. $1 B$ ) or by PCR using a set of primers: the intron 4 primer, 5'-ACTGATACTACCATCACTGG-3', and the intron 5 primer, $5^{\prime}$-AGCATATATAGGAAATTGCAGTAACCCT-3', followed by XbaI digestion. By using one of the three positive ES clones identified, germ-line transmitting male founder chimeric mice were generated, which led to establishment of $V G V$ and INI alleles in mice. The $5-H T_{2 C} R$ gene is X-linked, and thus hemizygous male and heterozygous and homozygous female mutant mice in both C57BL/6J and $\mathrm{BALB} / \mathrm{c}$ genetic backgrounds (more than six times backcrossed) were used for phenotypic analysis.

Drugs. Disodium $(R R)-5$-[2-[[2-(3-chlorophenyl)-2-hydroxyethyl]amino]propyl]-1,3-benzodioxazole-2,2-dicarboxylate (CL316243), 1-(m-chlorophenyl)-piperazine (mCPP), 6-chloro-5-methyl-1-[[2-[(2methyl-3-pyridyl)oxy]-5-pyridyl] carbamoyl]-indoline (SB242084), ketanserin, $N$-(1-methyl-1 $H$-5-indolyl)- $N^{\prime}$-(3-methyl-5-isothiazolyl)urea (SB204741), haloperidol, $R(+)$-7-chloro-8-hydroxy-3-methyl-1phenyl-2,3,4,5-tetrahydro- $1 H$-3-benzazepine hydrochloride $[R(+)$ SCH23390], $S(-)$-eticlopride, spiperone, mianserin, and $( \pm)-8$ hydroxy-2-(di- $n$-propylamino)tetralin hydrobromide (8-OH-DPAT) were obtained from Sigma-Aldrich. 6-Chloro-2-(1-piperazinyl)pyrazine hydrochloride (MK212) and (aS)-6-chloro-5-fluoro- $a$-methyl- $1 \mathrm{H}$ indole-1-ethanamine fumarate (Ro60-0175) were obtained from Tocris Bioscience. SB242084 was dissolved in 8\% 2-hydroxypropl- $\beta$ cyclodextrin (Sigma-Aldrich). Ketanserin, SB204741, and haloperidol were dissolved in DMSO. Spiperone was dissolved in ethanol, and others were dissolved in saline.

Blood chemistries. Whole blood was collected from the heart and kept at room temperature for $1 \mathrm{~h}$. After centrifugation at $8000 \mathrm{rpm}$ for $10 \mathrm{~min}$, the serum was transferred to new tubes and kept at $-80^{\circ} \mathrm{C}$ until use. Serum cholesterol and triglyceride levels were measured by Ani-Lytics. Serum hormone levels were measured by the University of Pennsylvania Diabetes Center Core Service Facilities. Serum insulin-like growth factor-1 (IGF-1), growth hormone (GH), insulin, leptin, corticosterone, and thyroxine (T4) were measured using ELISA kits [IGF-1 and GH (Diagnostic Systems Laboratories); insulin (ALPCO); leptin and corticosterone (Linco Research); T4 (MP Biomedicals)]. Serum active ghrelin was measured using radioimmunoassay kit (Linco Research) by adding $1 \mathrm{~N} \mathrm{HCl}$ at a final concentration of $0.1 \mathrm{~N}$ immediately after plasma separation according to the manufacturer's instruction. Blood glucose levels in tail vein bleeds were measured using OneTouch Ultra (LifeScan).

Metabolic rate and activity measurements. Oxygen consumption rate was measured by indirect calorimetry using a four-chamber Oxymax system (Columbus Instruments). Motor activity was simultaneously determined by infrared beam interruption analysis. An individual mouse was placed into the chamber $30 \mathrm{~min}$ before the measurement. The oxygen consumption, respiratory exchange ratio (RER), and motor activity were measured every $30 \mathrm{~min}$ for $5 \mathrm{~h}$, and data from the last $4 \mathrm{~h}$ were combined to calculate the mean value. The effect of the $\beta_{3}$-AR-specific agonist CL316243 on metabolic rate was measured as previously described (Xie et al., 2006). The effect of the $5-\mathrm{HT}_{2 \mathrm{C}} \mathrm{R}$-selective agonist MK212 $(0.2 \mathrm{mg} / \mathrm{kg})$, the $5-\mathrm{HT}_{2 \mathrm{C}} \mathrm{R}$-selective antagonist SB242084 (0.01, 0.5 , and $4.0 \mathrm{mg} / \mathrm{kg})$, the $5-\mathrm{HT}_{2 \mathrm{~A}} \mathrm{R}$-selective antagonist ketanserin $(0.6$ $\mathrm{mg} / \mathrm{kg})$, and the $5-\mathrm{HT}_{2 \mathrm{~B}} \mathrm{R}$-selective antagonist SB204741 $(3.0 \mathrm{mg} / \mathrm{kg})$ on metabolic rate and motor activity was also measured for $30 \mathrm{~min}$ before and for $5 \mathrm{~h}$ after intraperitoneal injection. In an attempt to identify the pathway activated during hyperlocomotion induced by SB242084, the $\mathrm{D}_{2}, \mathrm{D}_{3}$, and $\mathrm{D}_{4}$ dopamine receptor antagonist haloperidol $(0.75 \mathrm{mg} / \mathrm{kg})$, the $\mathrm{D}_{1}$ dopamine receptor antagonist $R(+)-\mathrm{SCH} 23390(0.2 \mathrm{mg} / \mathrm{kg})$, and the $\mathrm{D}_{2}$ dopamine receptor antagonist $S(-)$-eticlopride $(0.3 \mathrm{mg} / \mathrm{kg})$ was injected intraperitoneally $30 \mathrm{~min}$ before injection of SB242084 (0.5 mg/ $\mathrm{kg}$ ) followed by determination of the motor activity for $5 \mathrm{~h}$.

Genotyping of $\mathrm{Mc}_{\mathrm{r}} \mathrm{r}^{-/-}$mice. Genotyping of LoxTB:Mc4r $\left({\left.\mathrm{Mc} 4 r^{-/-}\right)}^{-}\right.$ mice was previously described (Balthasar et al., 2005). Briefly, pups were genotyped by PCR using three primers (MC4RFW1, 5'-GCACTACAGCGAGTCTCAGG-3'; MC4RFW2, 5'-GTGCAAGTGCAGGTGCCAG-3'; MC4RDW1, 5'-CTCCAACAGGCTTATGACACC-3'). MC4RFW2/MC4RDW1 primer pairs detect the loxP modified allele, whereas MC4RFW1/MC4RDW1 primer pairs detect an endogenous genomic $M c 4 r$ fragment.

Food intake studies. Mice were individually caged and had ad libitum access to water and a standard rodent diet containing 20\% (w/w) protein and $30 \%(\mathrm{w} / \mathrm{w})$ fat. Body weight was determined at the beginning of the dark cycle (6:00 P.M.). After $24 \mathrm{~h}$, remaining food and body weight were determined again everyday between 3 and 8 weeks of age and also between 15 and 16 weeks of age or between 5 and 8 weeks of age.

Food intake studies with $5-H T_{2 C} R$ agonist and antagonist. The effect of $5-\mathrm{HT}_{2 \mathrm{C}} \mathrm{R}$ agonist and antagonist on food intake was measured as previously described (Stark et al., 2006) with minor modification. Adult wildtype and $V G V$ male mice were individually caged and fasted overnight. At light off (6:00 P.M.), mice received a single dose of the $5-\mathrm{HT}_{2 \mathrm{C}} \mathrm{R}$ preferential agonist $\mathrm{mCPP}(0.2,5.0 \mathrm{mg} / \mathrm{kg})$, the $5-\mathrm{HT}_{2 \mathrm{C}} \mathrm{R}$-selective agonist MK212 $(0.2 \mathrm{mg} / \mathrm{kg})$, the $5-\mathrm{HT}_{2 \mathrm{C}} \mathrm{R}$-selective antagonist SB242084 $(0.01 \mathrm{mg} / \mathrm{kg})$, or control saline intraperitoneally ( $n=7$ for each group). Food intake was determined 2 and $24 \mathrm{~h}$ after presentation of food.

Temperature measurements and time course of 8-OH-DPAT-induced hypothermia. In all the experiments, body temperature of mice was measured with a digital thermometer (TH5 Thermalert Monitoring Thermometer; Physitemp Instruments) with a probe for mice inserted $1.0 \mathrm{~cm}$ into the rectum. All temperatures were measured at ambient temperature $\left(21 \pm 1^{\circ} \mathrm{C}\right)$. Basal temperature was measured $30 \mathrm{~min}$ and immediately before the subcutaneous injection of $8-\mathrm{OH}-\mathrm{DPAT}(1 \mathrm{mg} / \mathrm{kg})$. Body temperature was recorded every $15 \mathrm{~min}$ for $1 \mathrm{~h}$ after injection.

Preparation of RNA. Total RNA was extracted from dissected tissues by homogenizing in TRIzol reagent (Invitrogen).

Quantitative reverse transcription-PCR. To prepare an internal standard, gene-specific PCR products of $>1 \mathrm{~kb}$ in length were amplified. After gel purification, serial dilutions of each PCR product ranging from $10^{3}$ to $10^{8}$ copies per $1 \mu \mathrm{l}$ of the DNA solution, which contained $50 \mathrm{ng}$ of salmon sperm DNA were prepared. First-strand cDNA was synthesized using $1 \mu \mathrm{g}$ of total RNA and oligo-dT primer, followed by real-time PCR using a 7000 Sequence Detection System (Applied Biosystems). The following primer sets were used (amplified product lengths are also indicated): primer set for $5-H T_{2 C} R$ mRNA, $156 \mathrm{bp}, 5^{\prime}$-ATAGCCGGTTCAATTCGCG-3' and 5' $5^{\prime}$-AAGTTCGGGTCATTGAGCACG-3'; $\beta_{3^{-}}$ adrenergic receptors $\left(\beta_{3}-A R\right)$ mRNA, $124 \mathrm{bp}, 5^{\prime}$-CTCCAGAAAGAC- 
AAGCAACGG-3' and 5'-CCTCGTGGTCTAGTCATCGGTT-3'; uncoupling protein 1 (UCP1) mRNA, 211 bp, 5'-TACCAAGCTGTGCGATGT-3' and 5'-AAGCCCAATGATGTTCAGT-3'; $\beta$-actin mRNA, $143 \mathrm{bp}, 5^{\prime}$ GTATCCATGAAATAAGTGGTTACAGG-3' and 5'-GCAGTACATAATTTACACAGAAGCAAT- $3^{\prime}$. The relative amount of mRNA was calculated with $\beta$-actin mRNA as an internal control.

Analysis of adipose tissues. Dorsoscapular white adipose tissue (DWAT), epididymal white adipose tissue (EWAT), brown adipose tissue (BAT), total brain, and various tissues were dissected and stored at $-80^{\circ} \mathrm{C}$ until analysis after weight measurement.

Determination of $5-H T_{2 C} R$ agonist toxic effects. The effect of the $5-\mathrm{HT}_{2 \mathrm{C}} \mathrm{R}$-selective agonist MK212 and Ro60-0175, and the 5-HT $2 \mathrm{C}$ preferential agonist $\mathrm{mCPP}$ were measured as previously described (Lucki et al., 1989). Briefly, both drugs were dissolved in $0.9 \%$ saline and injected intraperitoneally at the dose of $0.2,0.3,0.5,1.0,10$, 20 , and $50 \mathrm{mg} / \mathrm{kg}$. Each drug was injected for adult wild-type, $V G V$, and INI male mice $(n=4)$ to measure the sufficient dose to induce seizure to death for all the mice within $30 \mathrm{~min}$.

$5-H T_{2 C} R$ autoradiography. Receptor binding assay was done as previously described (LópezGiménez et al., 2002) with modification. Whole brains from adult wild-type, $V G V$, and INI male mice $(n=3)$ were rapidly frozen after removal, and then kept at $-80^{\circ} \mathrm{C}$ until use. Frozen sections of $20 \mu \mathrm{m}$ thickness were prepared with the cryostat and mounted on slide glasses, and then quickly dried at room temperature. The slides were kept at $-80^{\circ} \mathrm{C}$ until use. Tissues were preincubated in buffer C (50 mm Tris-HCl, pH 7.6, $4 \mathrm{mM} \mathrm{CaCl}_{2}, 0.1 \%$ ascorbic acid) at room temperature for $30 \mathrm{~min}$, and then incubated with a mixture of $0.14 \mathrm{~nm}( \pm)-1-(2,5$-dimethoxy-4$\left[{ }^{125} \mathrm{I}\right]$ iodophenyl)-2-amino-propane $[( \pm)$ $\left.\left[{ }^{125} \mathrm{I}\right] \mathrm{DOI}\right]\left(5-\mathrm{HT}_{2 \mathrm{~A} / 2 \mathrm{C}} \mathrm{R}\right.$ agonist; PerkinElmer Life and Analytical Sciences) and $10^{-7} \mathrm{M}$ cold spiperon $\left(5-\mathrm{HT}_{2 \mathrm{~A}} \mathrm{R}\right.$-specific antagonist) in buffer $\mathrm{C}$ at room temperature for $60 \mathrm{~min}$. After washing twice in ice-cold buffer $\mathrm{C}$, tissues were dipped in distilled ice-cold water and dried rapidly under a cold air stream, and then exposed to films for $10 \mathrm{~d}$. We confirmed that a combination of $( \pm)-\left[{ }^{125} \mathrm{I}\right] \mathrm{DOI}$ with $10^{-5} \mathrm{M}$ cold mianserin (5- $\mathrm{HT}_{2 \mathrm{~A} / 2 \mathrm{C}} \mathrm{R}$ antagonist) generated complete blank, whereas the labeling was not significantly changed when spiperon was used as a cold competitor at the concentration ranging from $10^{-5}$ to $10^{-7} \mathrm{M}$. $5-\mathrm{HT}_{2 \mathrm{C}} \mathrm{R}$ binding sites within select brain regions such as choroid plexus, arcuate nucleus of the hypothalamus (Arc), and paraventricular nucleus of the hypothalamus $(\mathrm{PVH})$ were determined by measuring the optical density of autoradiographs. Nonspecific signal (background density) was subtracted from the total signal, resulting in the specific signal for each tissue section as previously described (Bale et al., 2001).

Statistical analyses. All the statistical analyses except for body temperature measurements were performed using the Mann-Whitney $U$ test. Two-way ANOVA with one repeated measure (time) followed by Fisher's post hoc tests were used for analysis of body temperature measurement data. All values are displayed as the mean \pm SEM. Differences were considered to be statistically significant when $p<0.05$.

\section{Results}

\section{Perturbation of growth in VGV mice}

Two mutant mouse lines harboring a knock-in VGV or INI allele were generated (Fig. 1A,B). The hemizygous male and homozy- gous female mice of these $\mathrm{X}$-linked mutated alleles solely express the fully edited VGV isoform or the completely unedited INI isoform receptor (supplemental Fig. S1, available at www. jneurosci.org as supplemental material). It has been reported that the editing pattern controls the alternative splice site selection and the expression of full-length and functional receptors (Fig. 1A) (Wang et al., 2000; Flomen et al., 2004). However, splicing patterns, and tissue and brain-region specific distribution of 5- $H T_{2 C} R$ mRNAs and proteins and their expression levels were identical between mutant and wild-type mice (supplemental Figs. S1 A, S2, S3, available at www.jneurosci.org as supplemental material). INI mice grew normally (supplemental Fig. S4, available at www.jneurosci.org as supplemental material), whereas $V G V$ mice, although born with normal body weight, demonstrated a dramatic decrease in growth rate especially during the first 3 weeks of postnatal development $(>50 \%$ reduction in body weight gain) (Figs. 1C,D, $2 A, B$ ). It has been reported that the pattern of $5-H T_{2 C} R$ mRNA editing is significantly different among inbred strains of mice. In C57BL/6 mice, the frequency of 

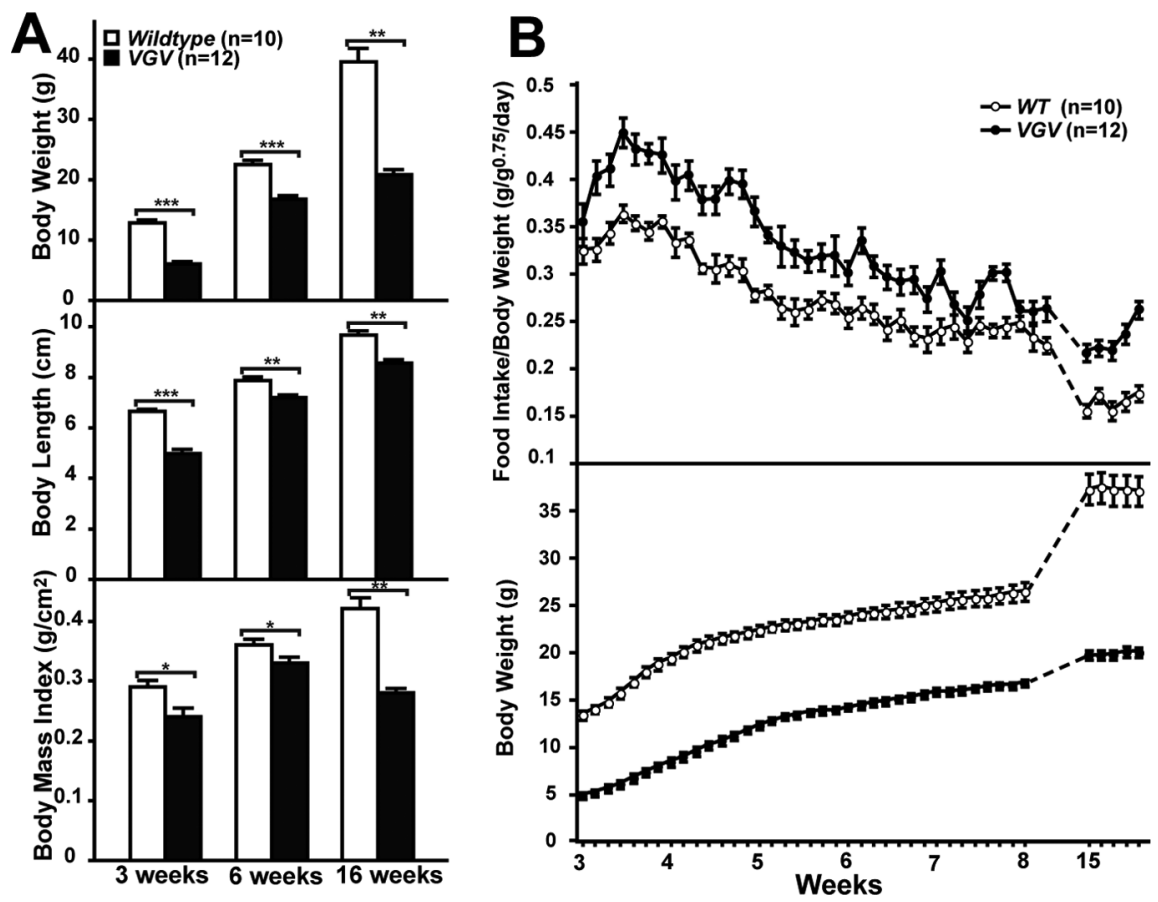

Figure 2. Analysis of growth rate and food intake of VGV mice. $A$, Body weight, nasoanal body length, and body mass index of wild-type and VGV male mice presented as the mean \pm SEM. Significant differences are indicated by asterisks (Mann-Whitney $U$ test; $\left.{ }^{*} p<0.05,{ }^{* *} p<0.01,{ }^{* * *} p<0.001\right)$. B , Daily food intake and body weight change.

$5-H T_{2 C} R$ mRNA editing is substantially higher than that in $\mathrm{BALB} / \mathrm{c}$ mice. In $\mathrm{BALB} / \mathrm{c}$ mice with lower serotonin levels caused by a defective serotonin synthesis pathway, $\sim 80 \%$ of $5-H T_{2 C} R$ mRNA remains unedited, resulting in the dominant expression of the INI receptor (Englander et al., 2005). Thus, we anticipated more severe phenotypic changes in BALB/c $V G V$ mice, but no strain difference was observed between $I N I$ or $V G V$ mice made in the $\mathrm{C} 57 \mathrm{BL} / 6 \mathrm{~J}$ and $\mathrm{BALB} / \mathrm{c}$ backgrounds (data not shown). Accordingly, most experiments hereafter were conducted with mice in the C57BL/6J background. The growth retardation was not caused by poor maternal care or nursing capability of mutant mother mice, because the phenotype of mutant pups raised by wild-type foster mothers did not revert (data not shown). Although the survival rate of hemizygous male $V G V$ mice nursed together with wild-type and heterozygous female littermates was $<20 \%$ during the first 2 weeks after birth, the rate recovered to $80 \%$ when littermate competition was removed (supplemental Fig. S5A, available at www.jneurosci.org as supplemental material). The reduced growth rate was detected also in heterozygous $V G V$ female mice (supplemental Fig. S5B, available at www. jneurosci.org as supplemental material) as well as VGV:INI hybrid female mice generated from crossing of $V G V$ and INI mice (data not shown), indicating the dominant effects of VGV isoform receptor expression. After weaning, the growth rate of mutant mice increased and became parallel to that of their wild-type littermates between 3 and 5 weeks (Fig. 1C). However, the body weight increase of $V G V$ mice thence flattened, leading to a weight disparity of 7-10 g (3-8 weeks) and $20 \mathrm{~g}$ (later adult life) for $V G V$ mice (Fig. 2A,B; supplemental Fig. S5B, available at www. jneurosci.org as supplemental material). The body length difference between wild-type and $V G V$ mice became less significant after weaning, resulting in an additional reduction in body mass index of the mutant mice at 16 weeks (Fig. $2 A$ ). Sexual maturation of hemizygous male and homozygous female $V G V$ and $I N I$ mice was normal, and they produced normal-size litters (Fig. 1C). Because growth retardation of $V G V$ mice was detected regardless of sex, most experiments were conducted with male mice unless noted otherwise.

Growth retardation of $V G V$ mice is not caused by growth hormone deficiency Reduced circulating IGF-1 levels were detected in $V G V$ mice (supplemental Fig. S6 A, available at www.jneurosci.org as supplemental material). Because hepatic IGF-1 synthesis is GH dependent, and serotonin is one of the neuromodulators that stimulates GH secretion by the pituitary, GH deficiency was suspected in $V G V$ mice. However, on measurement, circulating GH levels were high, not low (supplemental Fig. S6 B, C, available at www. jneurosci.org as supplemental material). In addition, daily injections of mouse recombinant $\mathrm{GH}$ from the postnatal day 4 to day 21 failed to rescue the growth retardation phenotype of $V G V$ mice (supplemental Fig. S6D, available at www.jneurosci. org as supplemental material). Together, these findings indicate that $V G V$ mice have no deficiency in GH synthesis or secretion by the pituitary through neonatal and/or adult life. Normal pituitary function was further supported by normal sexual maturation as well as normal thyroxine (T4) and corticosterone levels in $V G V$ mice (Fig. $3 A, B$ ).

\section{Hyperphagic and lean $V G V$ mice}

Reduced blood glucose levels at 3 weeks and consistently lower insulin levels (Fig. 3C,D) but normal glucose tolerance (data not shown) were also detected in $V G V$ mice. In addition, reduced leptin and increased ghrelin levels, both stimulating appetite, were noted in $V G V$ hemizygous males at 3 weeks, but they reached normal levels by 6 weeks (Fig. $3 E, F$ ). Most noticeably, $V G V$ mice had dramatically reduced fat accumulation in adipose tissues (white and brown) (Fig. 4A). Furthermore, blood cholesterol and triglyceride levels were substantially reduced (Fig. $4 B, C)$. These results collectively indicate negative balance of energy homeostasis in $V G V$ mice, possibly because of hypophagia. However, $V G V$ mice were hyperphagic, exceeding wild-type mice in their daily food intake when normalized by their body weight (Fig. $2 B$, top panel).

\section{Increased energy expenditure in $V G V$ mice}

Hyperphagic yet lean phenotypes indicated the possibility that physical activity and energy expenditure might be increased in $V G V$ mice. Oxygen consumption measurements conducted with 6-week-old $V G V$ mice indeed revealed an $\sim 40 \%$ increase of the metabolic rate in $V G V$ mice compared with wild-type mice (Fig. $5 A$ ), although physical activity was reduced twofold in $V G V$ mice (Fig. 6A). Hyperphagia, observed after weaning of $V G V$ mice, may be a compensatory reaction to the consistent negative balance of energy homeostasis caused by dramatically increased energy expenditure. Nutrition supplied solely in the form of milk during the preweaning period may not be sufficient to balance the overly increased energy expenditure of growing $V G V$ pups. 

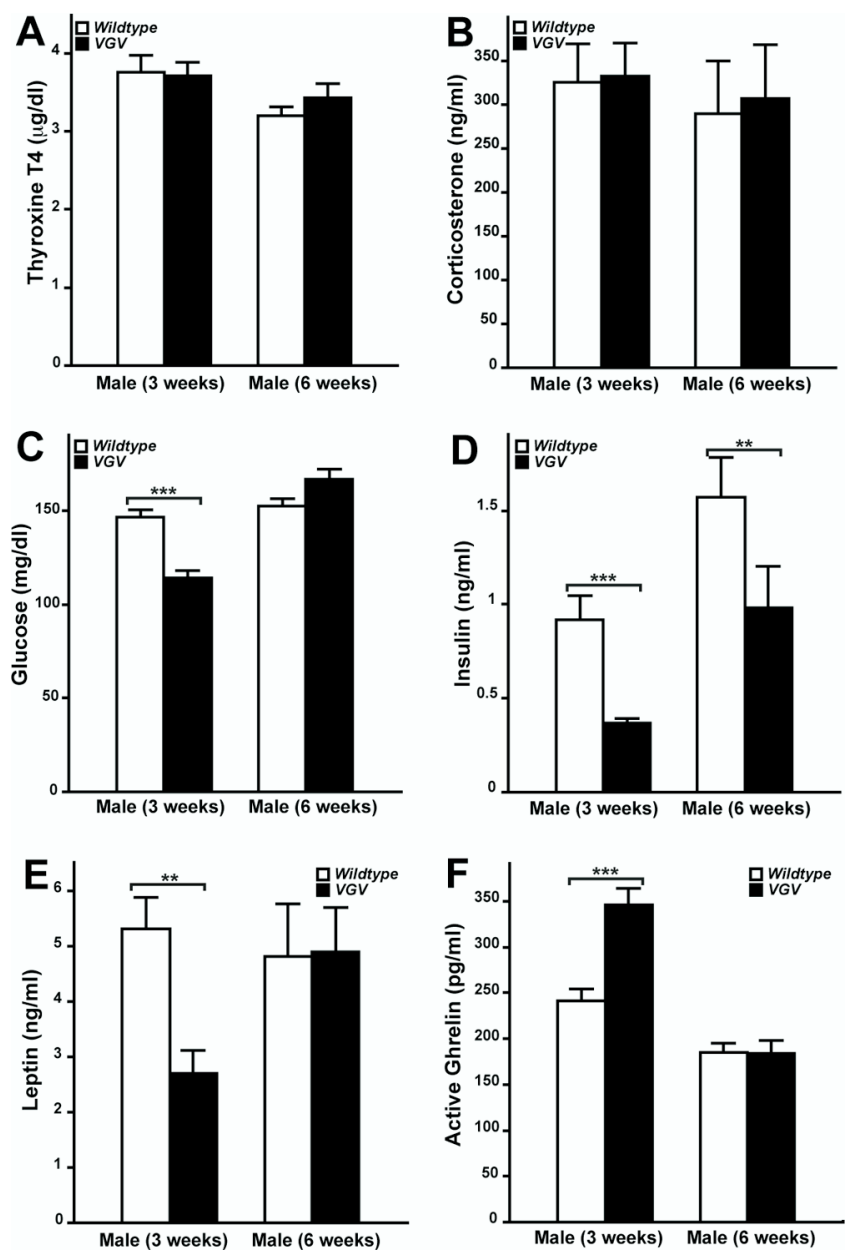

Figure 3. Levels of plasma parameters of energy homeostasis and hormones affecting appetite in VGV mice. T4 $(\boldsymbol{A})$ and corticosterone ( $\boldsymbol{B}$ ) levels of wild-type and VGV male mice at two different postnatal stages ( 3 and 6 weeks) were displayed as the mean \pm SEM $(n=11-22)$. № significant change of serum T4 and corticosterone levels was observed in VGV mice at either stage (Mann-Whitney $U$ test). Serum glucose $(\boldsymbol{C})$ and insulin levels $(\boldsymbol{D})(n=24-43)$ as well as serum leptin $(\boldsymbol{E})$ and active ghrelin $(\boldsymbol{F})(n=11-16)$ were also examined. Insulin levels of VGV mice were significantly decreased at 3 and 6 weeks $\left.{ }^{* *} p<0.01 ;{ }^{* * *} p<0.001\right)$. Serum glucose and leptin levels of VGV mice were significantly decreased at 3 weeks $\left({ }^{* *} p<0.01\right.$; ${ }^{* * *} p<$ $0.001)$, but there was no difference at 6 weeks $(p>0.05)$. In contrast, active ghrelin levels of VGV mice were significantly increased at 3 weeks ( ${ }^{* * *} p<0.001$ ), but not at 6 weeks ( $p>$ 0.05).

Milk intake is primarily limited by maternal milk provision, because the satiety mechanism does not develop until midway through the postnatal phase (Bouret et al., 2004; Plagge et al., 2004). Thus, substantially reduced IGF-1, glucose, and insulin levels are likely to reflect states of undernutrition in $V G V$ mice. Furthermore, reduction in leptin and increase in ghrelin levels, detected particularly immediately after weaning, indicates that the hormonal feedback mechanisms stimulate appetite to compensate for the persistent overexpenditure of energy in the mutant mice.

The sympathetic nervous system is constitutively activated in $V G V$ mice

The sympathetic nervous system (SNS) plays a critical role in the control of energy expenditure. The innervation of sympathetic preganglionic neurons to adipose tissues stimulates lipolysis and thermogenesis via $\beta_{3}$-AR (Hücking et al., 2003; Lowell and Bachman, 2003; Xie et al., 2006). There is no reliable antagonist that
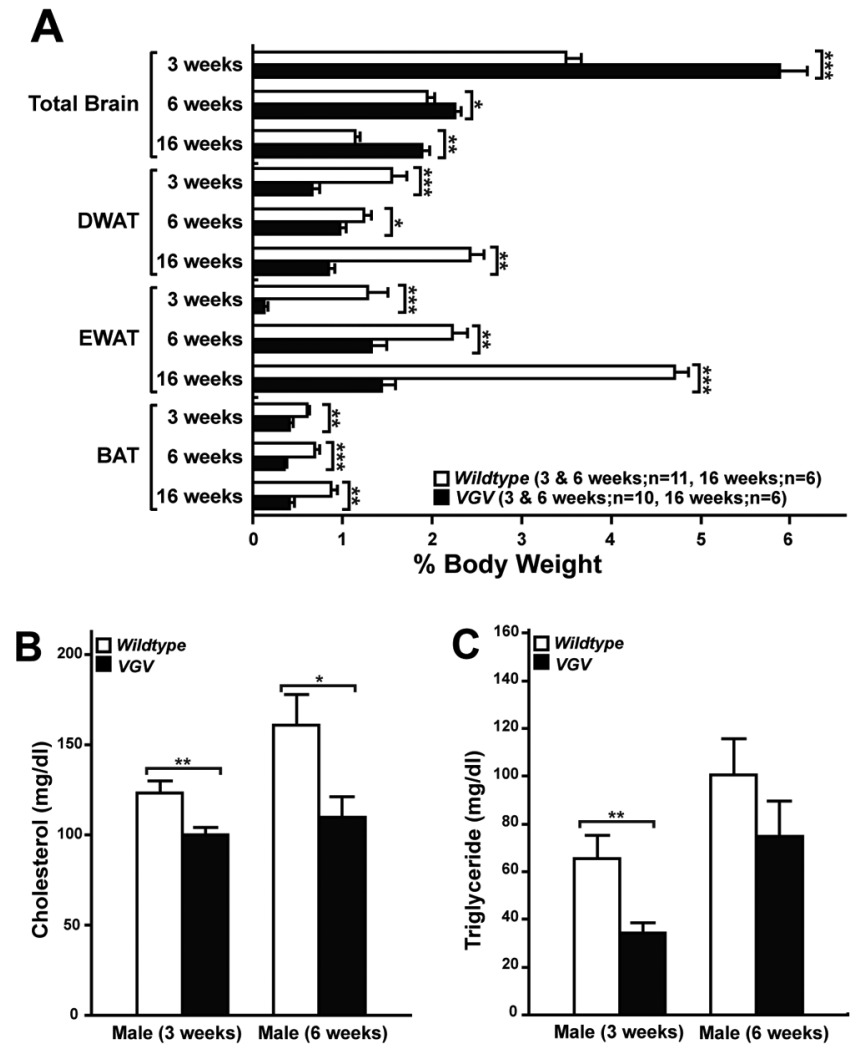

Figure 4. Fat mass and metabolism of VGV mice. $A$, Total brain, DWAT, EWAT, and interscapular BAT were dissected and weighed. The brain develops almost normally, resulting in its increased relative ratio to the remaining body weight of $V G V$ mice. $B, C$, Serum total cholesterol $(\boldsymbol{B})$ and triglyceride $(\boldsymbol{C})$ levels were also examined for wild-type $(n=11)$ and VGV mice $(3$ weeks, $n=11 ; 6$ weeks, $n=13$ ). Significant differences were detected for cholesterol levels between wild-type and VGV mice at 3 and 6 weeks and for triglyceride levels at 3 weeks $\left({ }^{*} p<\right.$ $\left.0.05,{ }^{* *} p<0.01 ;{ }^{* * *} p<0.001\right)$. Error bars indicate SEM.

suppresses $\beta_{3}$-AR activities in vivo. Therefore, we used a $\beta_{3}$-ARspecific agonist CL316243 (30 $\mu \mathrm{g} / \mathrm{kg}$, i.p.), which increased the metabolic rate of wild-type mice to a level comparable in $V G V$ mice, whereas it had no effect on $V G V$ mice (Fig. $5 A$ ), indicating that in the mutant mice $\beta_{3}$-ARs are constitutively already at their maximal activities. Activation of SNS is known to increase $\beta_{3}$-AR expression followed by upregulation of UCP1, a mitochondrial protein specifically expressed in brown adipose tissue (Lindqvist et al., 2007). $\beta_{3}-A R$ mRNA levels were elevated in brown adipose tissue of $V G V$ mice by 3.5- and 1.6-fold at 3 and 6 weeks, respectively, compared with wild-type mice (Fig. $5 B$ ). In addition, UCP1 mRNA levels were increased in brown adipose tissue of $V G V$ mice by twofold and fourfold, respectively, compared with wild-type mice (Fig. 5C). Together, these results indicate that the elevated energy expenditure and reduced fat accumulation of $V G V$ mice are likely to have resulted from constitutively activated SNS activity.

Normal body temperature of $V G V$ mice regulated by a 5$\mathrm{HT}_{1 \mathrm{~A}} \mathrm{R}$-mediated feedback mechanism

We reasoned that the elevated sympathetic tone and BAT thermogenesis might result in increase of the body temperature in $V G V$ mice. However, there was no significant difference in the basal body temperature between $V G V$ and counterpart wild-type mice (Fig. 7A). The normal body temperature of $V G V$ mice may indicate the presence of a counteracting mechanism operating in $V G V$ mice. It has been reported that normal levels of serotonin 

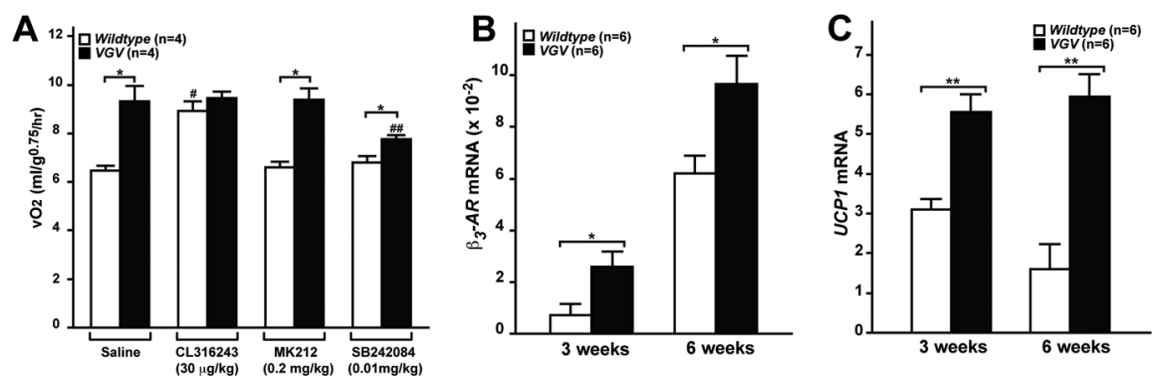

Figure 5. Constitutively activated sympathetic nervous system and increased energy expenditure in VGV mice. $A$, Metabolic rates of wild-type and VGV male mice ( 6 weeks of age) measured with or without intraperitoneal injection of the $\beta_{3}$-AR agonist (CL316243), $5-\mathrm{HT}_{2 \mathrm{C}} \mathrm{R}$-selective agonist (MK212), or antagonist (SB242084) are presented as the mean \pm SEM. No difference in RER was detected (data not shown). $\boldsymbol{B}$, The $\beta_{3}$-AR mRNA levels in BAT. The relative $\beta_{3}$-AR mRNA amount is presented as the mean \pm SEM. C, The UCP1 mRNA levels in BAT. The relative UCP1 mRNA amount is presented as the mean \pm SEM. $A-C$, Significant differences are indicated by asterisks $\left({ }^{*} p<0.05 ;{ }^{* *} p<0.01\right) . A$, "Significantly different from three other values of the wild-type experiments $(p<0.05)$. ${ }^{\#}$ Significantly different from three other values of the VGV experiments $(p<0.05)$.
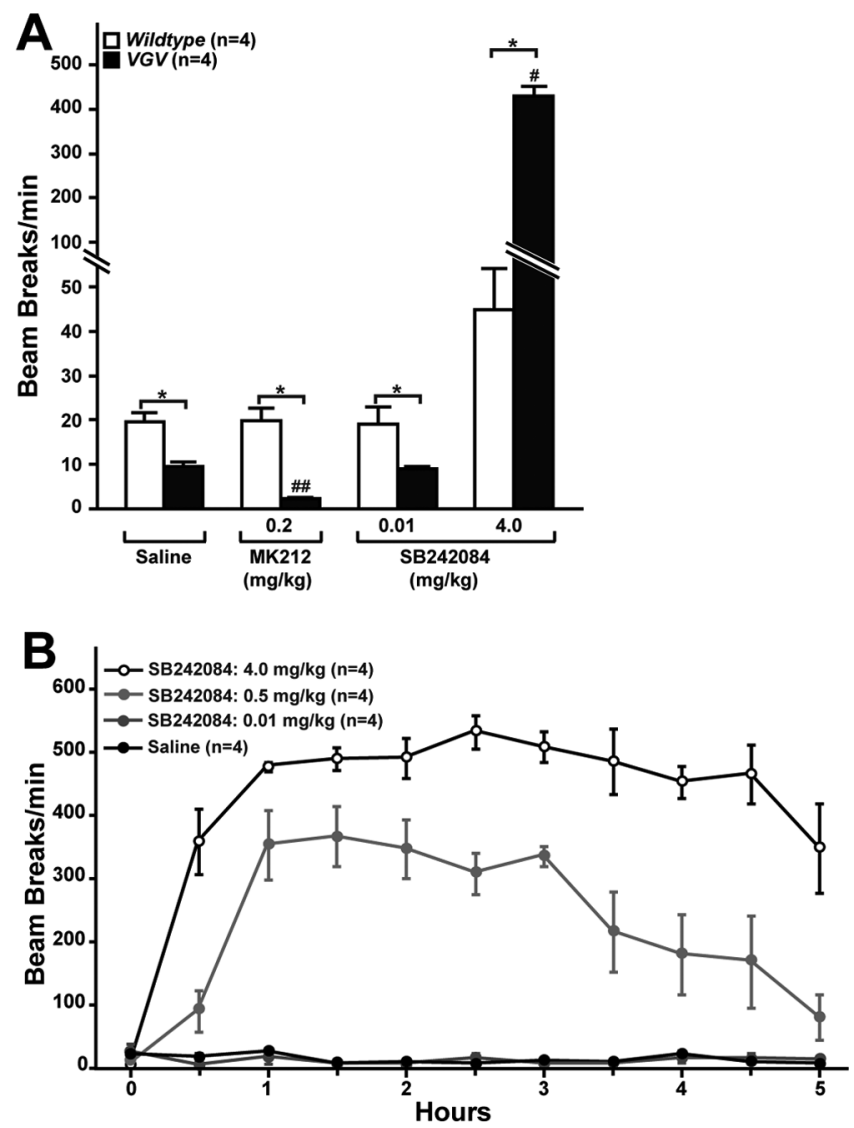

Figure 6. Hyperlocomotion induced in hypoactive VGV mice by the $5-\mathrm{HT}_{2} \mathrm{R}$ antagonist. $A$, Total activity levels detected in mice administered with the $5-\mathrm{HT}_{2} \mathrm{R}$-selective agonist or antagonist as infrared beam disturbance of $x y$-axis movement are presented as the mean \pm SEM. Significant differences are indicated by asterisks $\left({ }^{*} p<0.05\right)$. "Significantly different from

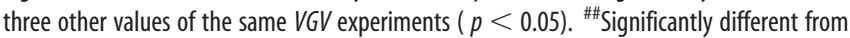
three other values of the same VGV experiments $(p<0.05)$. $\boldsymbol{B}$, The dose-dependent hyperlocomotion induced in $\mathrm{VGV}$ mice by the $5-\mathrm{HT}_{2} \mathrm{R}$-selective antagonist.

neuron firing that regulates heart rate, respiration, and body temperature are maintained by a negative-feedback inhibition mechanism via $5-\mathrm{HT}_{1 \mathrm{~A}}$ receptors $\left(5-\mathrm{HT}_{1 \mathrm{~A}} \mathrm{R}\right)$ in the medullary raphe (Richer et al., 2002; Nakamura and Morrison, 2007). Therefore, we investigated whether the $5-\mathrm{HT}_{1 \mathrm{~A}} \mathrm{R}$-mediated mechanism contributes to normal body temperature of $V G V$ mice by using a 5- $\mathrm{HT}_{1 \mathrm{~A}} \mathrm{R}$-specific agonist 8-OH-DPAT (Fig. 7A). Overall, effects of 8-OH-DPAT confirmed that 5- $\mathrm{HT}_{1 \mathrm{~A}} \mathrm{R}$ activation elicited hypothermia. However, more prominent 8-OH-DPAT-induced hypothermia was observed with $V G V$ mice compared with wild-type mice (Fig. 7A). In contrast, INI mice exhibited similar basal body temperature and 8-OH-DPATinduced hypothermia compared with wild-type mice (Fig. $7 B$ ). The results indicate that the body temperature of $V G V$ mice, which would be otherwise elevated, is set back to a normal level, most likely via a $5-\mathrm{HT}_{1 \mathrm{~A}} \mathrm{R}$-mediated compensatory mechanism.

Elevated energy expenditure of $V G V$ mice is regulated independent of the MC4R-mediated pathway

The Arc of the hypothalamus plays an important role in energy homeostasis. The Arc contains two distinct populations of neurons: one, preopiomelanocortin neurons expressing the anorexigenic $\alpha$-melanocyte-stimulating hormone $(\alpha-\mathrm{MSH})$, and the other expressing the orexigenic agouti-related protein (AgRP). $\alpha$-MSH and AgRP act as agonist and antagonist, respectively, for MC4R, which has been reported to regulate food intake (Heisler et al., 2006). In addition, MC4R regulates energy expenditure, most likely through SNS (Balthasar et al., 2005). $M c 4 r^{-1-}$ mice are obese because of hyperphagia and reduced energy expenditure (Huszar et al., 1997). It has been postulated that 5-HT exerts its effects upstream of the MC4R signaling pathway via $5-\mathrm{HT}_{1 \mathrm{~B}} \mathrm{R}$ and $5-\mathrm{HT}_{2 \mathrm{C}} \mathrm{R}$. $5-\mathrm{HT}_{1 \mathrm{~B}} \mathrm{R}$ is positioned to inhibit the pathway leading to release of AgRP, whereas $5-\mathrm{HT}_{2 \mathrm{C}} \mathrm{R}$ is positioned to exert its stimulatory effects on $\alpha$-MSH activity upstream of MC4R to regulate food intake (Heisler et al., 2002, 2006; Lam et al., 2008). It has recently been reported that $5-\mathrm{HT}_{2 \mathrm{C}} \mathrm{R}$ agonist also stimulates SNS, at least in part, through MC4R activation in the intermediolateral nucleus of the spinal cord (Zhou et al., 2007). To determine the relationship between $5-\mathrm{HT}_{2 \mathrm{C}} \mathrm{R}-\mathrm{VGV}$-mediated and MC4R-mediated signaling pathways, the growth rate of $V G V$ mice in the $M c 4 r^{-1-}$ background was determined (Fig. $8 A, B$ ). Although the growth rate of $V G V$ : $M c 4 r^{-/-}$mice became almost parallel to that of wild-type mice, especially after 9 weeks, it was still substantially lower than that of $M c 4 r^{-/-}$mice, suggesting that obesity of $M c 4 r^{-/-}$mice was rescued in the $V G V$ background (Fig. $8 A, B$ ). Substantially increased food intake detected with $V G V: M c 4 r^{-/-}$mice compared with $V G V$ mice (from 5 to 8 weeks) (Fig. $8 C$ ) must be responsible for larger body mass index of $V G V: M c 4 r^{-\prime-}$ mice than that of $V G V$ mice detected at 16 weeks (Fig. $8 B$ ). Most importantly, the energy expenditure increase detected with $V G V$ mice remained in $V G V: M c 4 r^{-/-}$mice, indicating that elevated energy expenditure of $V G V$ mice cannot be rescued in the $M c 4 r^{-/-}$background (Fig. $8 D)$.

Oversensitization of $5-\mathrm{HT}_{2 \mathrm{C}} \mathrm{R}$-mediated neurotransmission for locomotion, food intake, and energy expenditure in $V G V$ mice

The administration of the $5-\mathrm{HT}_{2 \mathrm{C}} \mathrm{R}$-selective agonist MK212 or $\mathrm{mCPP}$ has been shown to decrease locomotor activity and, at high dose, produce severe convulsions and death in rats (Lucki et al., 1989). To obtain insights into the hypoactive phenotype of $V G V$ mice, we examined the effects of the $5-\mathrm{HT}_{2 \mathrm{C}} \mathrm{R}$ agonists. Similar pharmacological effects (convulsions and death) of 
MK212 were produced but surprisingly at the 100 times lower dose $(0.5$ vs $50 \mathrm{mg} / \mathrm{kg}$, i.p.) in $V G V$ mice compared with wildtype mice (Table 1) as well as INI mice (data not shown). Similar low-dose toxic effects of two other $5-\mathrm{HT}_{2 \mathrm{C}} \mathrm{R}$ agonists, $\mathrm{mCPP}$ and Ro60-0175, were confirmed (data not shown). The administration of MK212 at the low dose that did not exhibit the toxic effects $(0.2 \mathrm{mg} / \mathrm{kg}$, i.p. $)$ resulted in more pronounced hypoactivity in $V G V$ mice, indicating that suppression of locomotion results directly from the activation of $5-\mathrm{HT}_{2 \mathrm{C}} \mathrm{R}$ (Fig. $6 \mathrm{~A}$ ). Finally, we investigated the effects of SB242084, a 5- $\mathrm{HT}_{2 \mathrm{C}} \mathrm{R}-$ specific antagonist. Interestingly, the administration of SB242084, but neither a $5-\mathrm{HT}_{2 \mathrm{~A}} \mathrm{R}$-specific antagonist ketanserin nor a $5-\mathrm{HT}_{2 \mathrm{~B}} \mathrm{R}$-specific antagonist SB204741 (data not shown), induced the dose-dependent hyperlocomotion in $V G V$ mice (Fig. $6 A, B$ ), confirming the presence of the signaling pathway mediated via $5-\mathrm{HT}_{2 \mathrm{C}} \mathrm{R}-\mathrm{VGV}$ that negatively controls the motor activities. The negative control must be released by the treatment of $V G V$ mice with the antagonist. The hyperlocomotion induced in $V G V$ mice was extreme (e.g., 10 times higher than that induced in wild-type mice by $4.0 \mathrm{mg} / \mathrm{kg} \mathrm{SB} 242084$ ) (Fig. 6A). The results indicate that the hypoactivity of $V G V$ mice is unlikely to result from a simple feedback mechanism in response to the increased energy expenditure. The constitutive activation of the serotonergic neurotransmission mediated via the VGV receptor appears to form a strong circuitry that negatively regulates locomotion. Sudden release of this inhibitory mechanism by the $5-\mathrm{HT}_{2 \mathrm{C}} \mathrm{R}$ antagonist seems to induce the reactive hyperlocomotion. During the induced hyperlocomotion, $V G V$ mice moved restlessly often in one direction, which was interrupted by occasional vigorous and sudden movement (i.e., jumping). The extreme hyperlocomotion resembled the kinetosis induced by overstimulation of dopaminergic neurotransmission (Ralph et al., 2001). Phasic and tonic inhibitory effects of the neurotransmission mediated via $5-\mathrm{HT}_{2 \mathrm{C}} \mathrm{R}$ over the mesocorticolimbic dopamine system have been reported previously (Di Matteo et al., 2001). To test the possible involvement of the dopaminergic neurotransmission in the mechanism that controls locomotion of $V G V$ mice, several dopamine receptor antagonists were examined. However, the administration of haloperidol $\left(\mathrm{D}_{2}, \mathrm{D}_{3}\right.$, and $\mathrm{D}_{4}$ dopamine receptor antagonist) could not revert the hyperlocomotion induced by the $5-\mathrm{HT}_{2 \mathrm{C}} \mathrm{R}$-specific antagonist (data not shown). A $D_{1}$ antagonist $R(+)$-SCH23390 known to attenuate the hyperlocomotion of the dopamine transporter knock-out mice (Ralph et al., 2001) and/or a $\mathrm{D}_{2}$ antagonist

A
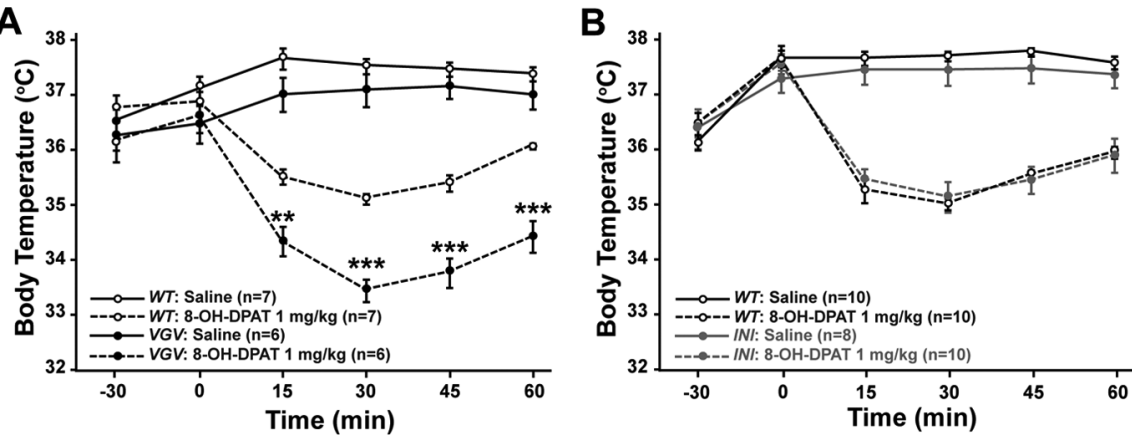

Figure 7. Enhanced hypothermic response induced in VGV mice by 8-OH-DPAT. Time course effects of 8-OH-DPAT (1 mg/kg, s.c.) on the decrease of body temperature in $V G V$ and wild-type $(\boldsymbol{A})$ or $I N I$ and wild-type mice $(\boldsymbol{B})$ are shown. Temperature values plotted are means \pm SEM of 6-7 mice for VGV and 8-10 mice for INI. Significant difference between VGV and wild-type mice treated with 8-OH-DPAT was noted $\left({ }^{* *}<0.01 ;{ }^{* * *}<0.001\right)$.
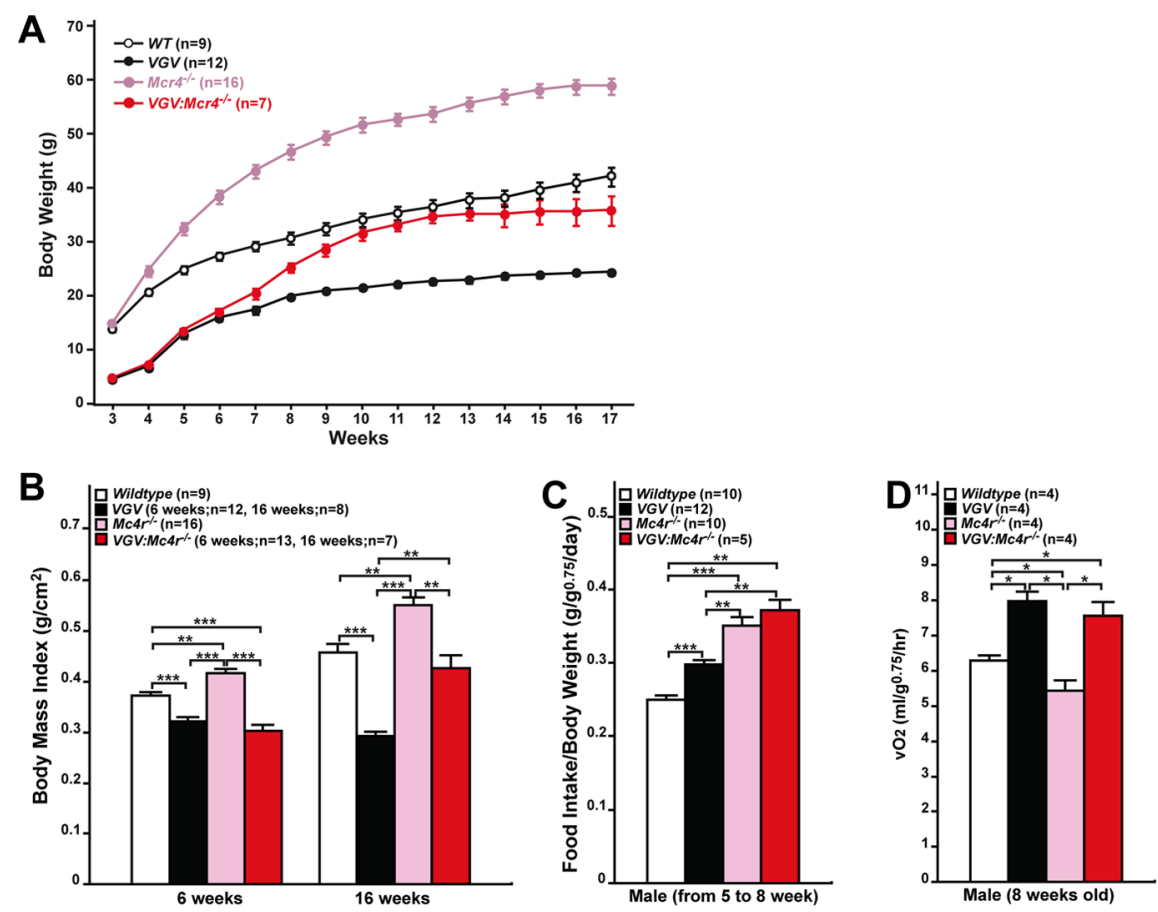

Figure 8. No rescue of increased energy expenditure of $V G V$ mice in the $M c 4 r^{-1-}$ genetic background. $A$, Growth rates of wild-type, $V G V, M c 4 r^{-1-}$, and $V G V: M c 4 r^{-1-}$ mice. $B$, Body mass index of $V G V: M c 4 r^{-1-}$ mice was significantly smaller than that of $M\left(4 r^{-\prime}-\right.$ mice at 16 weeks. C, More enhanced hyperphagia of $V G V$ mice in the $M c 4 r^{-\prime-}$ background. $D$, Elevated energy expenditure detected also in $V G V: M c 4 r^{-1-}$ mice. All experiments were conducted with male mice. $\boldsymbol{B}-\boldsymbol{D}$, Significant differences are indicated by asterisks $\left({ }^{*} p<0.05 ;{ }^{* *} p<0.01 ;{ }^{* * *} p<0.001\right)$. Error bars indicate SEM.

\section{Table 1. Toxic effects of $5-\mathrm{HT}_{2 \mathrm{C}} \mathrm{R}$-selective agonists on VGV mice}

\begin{tabular}{llllllll}
\hline & \multicolumn{7}{l}{ MK212 (mg/kg) } \\
\cline { 2 - 7 } Genotype & 0.2 & 0.3 & 0.5 & 1.0 & 10 & 20 & 50 \\
\hline Wild type & $0(0)$ & $0(0)$ & $0(0)$ & $0(0)$ & $0(0)$ & $3(0)$ & $4(4)$ \\
VGV & $0(0)$ & $1(0)$ & $4(4)$ & $4(4)$ & $4(4)$ & $4(4)$ & $4(4)$ \\
\hline
\end{tabular}

Four each of wild-type and VGV hemizygous males were examined. Indicated are the number of mice that had seizures and, in parentheses, the number of mice that underwent severe convulsions and death.

$S(-)$-eticlopride did not have significant effects either (data not shown). However, the extent of hyperlocomotion is extreme, and additional studies are required to exclude completely the involvement of the dopamine system in the mechanism affecting the locomotive activity of $V G V$ mice. Interestingly, these pharmacological experiments using $5-\mathrm{HT}_{2 \mathrm{C}} \mathrm{R}$ agonists and antagonists revealed that the dose required for induction of certain pharmaco- 

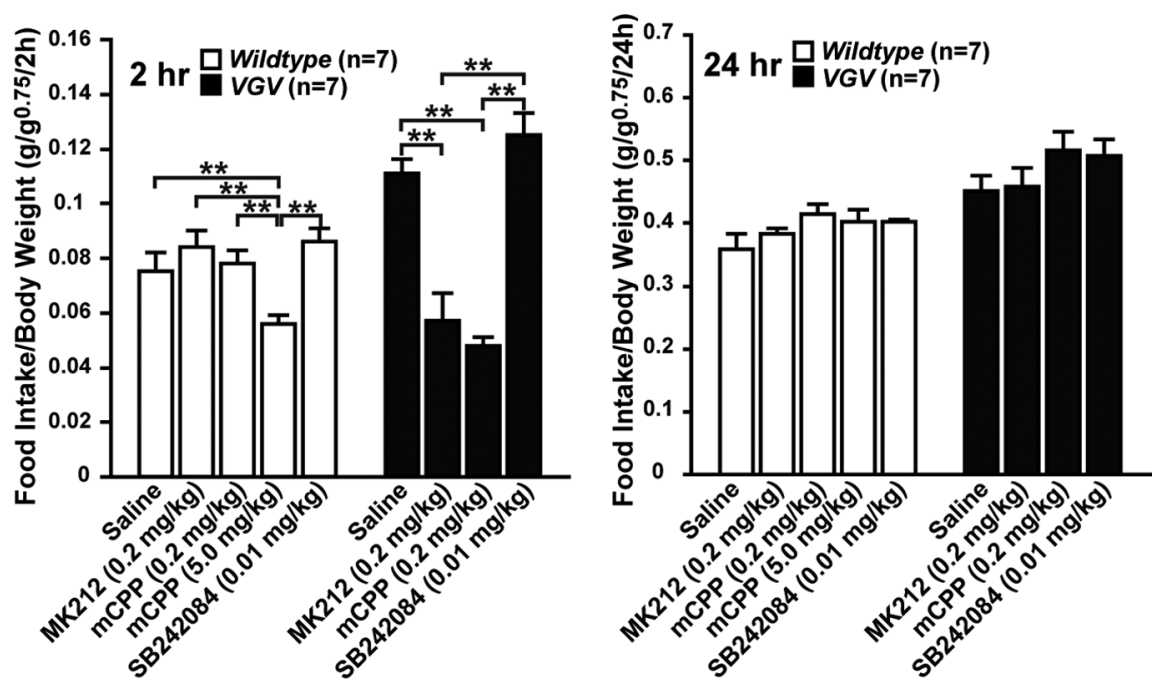

Figure 9. Effects of 5- $\mathrm{HT}_{2 c} \mathrm{R}$-selective agonist and antagonist on appetite. Cumulative food intake at 2 and $24 \mathrm{~h}$ after administration of $5-\mathrm{HT}_{2} \mathrm{R}$-selective agonist (mCPP and MK212) or antagonist (SB242084) presented as the mean \pm SEM. Significant differences are indicated by asterisks $\left({ }^{*} p<0.05 ;{ }^{* *} p<0.01 ;{ }^{* * *} p<0.001\right)$.

logical effects (i.e., convulsion or hyperlocomotion) is much lower in $V G V$ mice compared with wild-type mice, indicating that the serotonergic neurotransmission is overly sensitized in $V G V$ mice.

Consequently, we then conducted similar pharmacological studies on food intake and energy expenditure by using the low dose of the $5-\mathrm{HT}_{2 \mathrm{C}} \mathrm{R}$ agonist and antagonist that would not cause significant changes in locomotion. Food intake of $V G V$ mice was reduced substantially at $2 \mathrm{~h}$ after administration of the $5-\mathrm{HT}_{2 \mathrm{C}} \mathrm{R}$ selective agonist MK212 (0.2 mg/kg, i.p.) or mCPP $(0.2 \mathrm{mg} / \mathrm{kg}$, i.p.), although their suppressive effects were transient and lost at $24 \mathrm{~h}$ most likely because of their short half-lives (Fig. 9). The low-dose administration of the $5-\mathrm{HT}_{2 \mathrm{C}} \mathrm{R}$-selective antagonist SB242084 (0.01 mg/kg, i.p.) did not have any effects on hyperphagia of $V G V$ mice (Fig. 9). The results indicate that the anorectic effects of $5-\mathrm{HT}_{2 \mathrm{C}} \mathrm{R}$-mediated pathway (Heisler et al., $2002,2006)$ remains intact in $V G V$ mice but is masked by a separate mechanism that has more dominant orexigenic effects, leading to hyperphagia. It is noteworthy that the dose of the agonist that induced transient anorectic effects in $V G V$ mice was very low and did not have substantial effects on food intake of wild-type mice. The much higher dose of the agonist mCPP (5.0 $\mathrm{mg} / \mathrm{kg}$, i.p.) was required to observe the anorectic effects in wildtype mice, revealing once again the oversensitized serotonergic neurotransmission in $V G V$ mice. Together, these studies indicate that the hyperphagia of $V G V$ mice likely results from the constitutive suppression of the anorectic signaling pathway mediated via $5-\mathrm{HT}_{2 \mathrm{C}} \mathrm{R}$ (Heisler et al., 2002, 2006).

Finally we found that administration of the low-dose 5- $\mathrm{HT}_{2 \mathrm{C}} \mathrm{R}$-selective agonist MK212 (0.2 mg/kg, i.p.) had no additional effects on energy expenditure, indicating that the serotonergic neurotransmission projecting to SNS has been constitutively activated already to the maximal level (Fig. $5 A$ ). However, the low-dose administration of the $5-\mathrm{HT}_{2 \mathrm{C}} \mathrm{R}$-selective antagonist SB242084 (0.01 mg/kg, i.p.) reduced the energy expenditure significantly in $V G V$ mice, yet higher than that of the level of wild type, indicating that the increased energy expenditure results from the direct activation of $5-\mathrm{HT}_{2 \mathrm{C}} \mathrm{R}$ (Fig. $5 A$ ).
Increased agonist binding of the 5$\mathrm{HT}_{2 \mathrm{C}} \mathrm{Rs}$ in $V G V$ mice

To investigate the mechanism that results in oversensitization of serotonergic neurotransmission, quantitative receptor autoradiography was conducted. Either $( \pm)$ $\left[{ }^{125} \mathrm{I}\right] \mathrm{DOI} \quad\left(5-\mathrm{HT}_{2 \mathrm{~A}} \mathrm{R}\right.$ and $5-\mathrm{HT}_{2 \mathrm{C}} \mathrm{R}-$ specific agonist) or $\left[{ }^{3} \mathrm{H}\right]$ mesulergrine (5$\mathrm{HT}_{2 \mathrm{~A}} \mathrm{R}$ and $5-\mathrm{HT}_{2 \mathrm{C}} \mathrm{R}$-specific antagonist as well as inverse agonist) in the presence of the cold competitor spiperone, a specific antagonist to $5-\mathrm{HT}_{2 \mathrm{~A}} \mathrm{R}$, has been successfully used as the $5-\mathrm{HT}_{2 \mathrm{C}} \mathrm{R}$ tracer, and visualization of high density in choroid plexus but otherwise in general low density of the $5-\mathrm{HT}_{2 \mathrm{C}} \mathrm{R}$-specific binding sites in wild-type rodent brains has been reported (López-Giménez et al., 2002). Therefore, we used $( \pm)-\left[{ }^{125} \mathrm{I}\right] \mathrm{DOI}$ in the presence of the cold competitor spiperone for our experiments (Fig. 10A-I). The four times lower binding affinity of $( \pm)$-DOI to the VGV receptor compared with the INI receptor has been reported with the in vitro cell transfection system (Fitzgerald et al., 1999). To our surprise, however, the receptor autoradiography revealed that the $5-\mathrm{HT}_{2 \mathrm{C}} \mathrm{R}$-specific binding of the tracer was dramatically increased in the entire brain of $V G V$ mice compared with wild-type and INI mice. The difference could be clearly seen especially in certain brain regions. For instance, the binding sites in the fourth ventricle choroid plexus (ChP), Arc, and PVH of $V G V$ mice were twofold, fourfold, and fourfold higher than those of wild-type or INI mice, respectively (Fig. 10J). The apparent increase of ( \pm )$\left[{ }^{125} \mathrm{I}\right]$ DOI binding is not attributable to the relative increase of its binding to $5-\mathrm{HT}_{2 \mathrm{~A}} \mathrm{R}$ because of, for instance, increased binding of the VGV receptor to spiperone, because both VGV and INI receptors barely bind to this $5-\mathrm{HT}_{2 \mathrm{~A}} \mathrm{R}$-specific antagonist (Fitzgerald et al., 1999). No significant difference was detected in various brain regions between wild-type and INI mice. Together, these results revealed dramatically increased ligand binding sites in $V G V$ mice, most likely caused by increased expression of the functional VGV receptors.

\section{Discussion}

Editing isoforms of 5- $\mathrm{HT}_{2 \mathrm{C}} \mathrm{R}$ have been characterized previously only in vitro in non-neuronal cells transfected with various editing isoform expression plasmids (Burns et al., 1997; Fitzgerald et al., 1999; Niswender et al., 1999; Wang et al., 2000; Marion et al., 2004). However, the in vivo effects of $5-H T_{2 C} R$ mRNA editing have not been evaluated previously. In the present studies, we created mutant mice that solely express one of two extremely different editing isoform receptors, VGV (fully edited) and INI (editing blocked), to examine the in vivo significance of $5-H T_{2 C} R$ mRNA editing. We provided the first direct evidence through phenotypic analysis of these mutant mice that regulated editing is important, because overediting of $5-H T_{2 C} R$ mRNAs altered dramatically the mechanism that regulates energy homeostasis.

It has been reported that $5-H T_{2 C} R$-null mice exhibit hyperphagic and late-onset obesity phenotypes (Tecott et al., 1995). In contrast, $V G V$ mice expressing solely the VGV isoform had reduced fat mass and lipid accumulation in adipose tissue, and yet were hyperphagic and hypoactive through their postnatal and adult life. The lean and energy dissipating phenotypes of $V G V$ 
mice, different from the INI mouse phenotypes with normal growth and metabolic rates or late-onset obesity phenotypes of 5- $H T_{2 C} R$-null mice (Tecott et al., 1995), clearly indicate the presence of a distinct signaling pathway activated via the VGV receptor. This VGV-dependent pathway appears to activate a latent "gain-offunction" type mechanism that upregulates energy metabolism, because no opposite effects (reduced energy expenditure and obesity) were detected in INI mice. The presence of the mechanism is revealed in $V G V$ mice because a feedback mecha$\operatorname{nism}(\mathrm{s})$, which normally acts to reduce the inappropriately increased energy expenditure by reducing the extent of $5-H T_{2 C} R$ mRNA editing, is not available in this mutant mouse line with editing frequency set to $100 \%$ permanently. Serum GH, corticosterone, and thyroxine concentrations were all in the normal range in $V G V$ mice. Furthermore, no abnormality was noted for mating behavior of hemizygous male and homozygous female $V G V$ mice as well as their litter sizes, indicating normal pituitary function.

The increased energy expenditure appears to result from the constitutively activated SNS, because the increased expression of $\beta_{3}$-AR and UCP1 in brown fat tissues was detected in $V G V$ mice. Interestingly, basal body temperature of $V G V$ mice expected to be elevated by activated SNS and BAT thermogenesis was normal, perhaps regulated by the $5-\mathrm{HT}_{1 \mathrm{~A}} \mathrm{R}$ mediated feedback mechanism. The normal body temperature may help to prevent additional energy dissipation in VGV mice. MC4R has been proposed to play a major role in the regulation of energy metabolism and appetite by providing an essential node linking various pathways including one mediated via $5-\mathrm{HT}_{2 \mathrm{C}} \mathrm{R}$, and inactivation of this melanocortin receptor gene leads to increase in food intake and decrease in energy expenditure and consequent obesity (Huszar et al., 1997; Balthasar et al., 2005). However, the reduced energy expenditure of $M c 4 r^{-/-}$mice was reverted in the $V G V$ genetic background, whereas the elevated energy expenditure of $V G V$ mice remained in the $M c 4 r^{-/-}$genetic background. Our results indicate that the pathway activated via the VGV receptor that regulates energy expenditure is independent of the $\alpha$-MSHMC4R-mediated pathway. Furthermore, this neurotransmission activated via the VGV receptor has dominant effects over the MC4R-mediated pathway. Our experiments using $5-\mathrm{HT}_{2 \mathrm{C}} \mathrm{R}-$ selective agonists confirmed that the $5-\mathrm{HT}_{2 \mathrm{C}} \mathrm{R}-\mathrm{MC} 4 \mathrm{R}$-mediated signaling pathway that negatively regulates appetite is active in $V G V$ mice, because hyperphagia of the mutant mice can be transiently reverted by agonist administration. However, the administration of the $5-\mathrm{HT}_{2 \mathrm{C}} \mathrm{R}$-selective antagonist could not enhance hyperphagia of $V G V$ mice. It seems that a feedback mechanism strongly upregulates appetite to compensate the negative balance of energy homeostasis resulted from the overly activated SNS and consequent energy dissipation by reducing and masking the an- orectic effects of the $5-\mathrm{HT}_{2 \mathrm{C}} \mathrm{R}-\alpha-\mathrm{MSH}-\mathrm{MC} 4 \mathrm{R}$-mediated pathway.

The molecular basis of the VGV isoform action, leading to $V G V$ mouse phenotypes, is currently unknown. Previous in vitro studies in transfected non-neuronal cells suggested that G-protein coupling efficacy, basal level activities, and the agonist affinity of VGV isoform are dramatically reduced compared with the INI isoform receptor. For instance, the 5-HT potency of the VGV receptor is 20-30 times lower than that of the INI receptor, whereas binding affinity of the $5-\mathrm{HT}_{2 \mathrm{C}} \mathrm{R}$-selective agonist MK212 and $\mathrm{mCPP}$ to the VGV isoform is six times lower than that of the INI receptor (Burns et al., 1997; Fitzgerald et al., 1999; Niswender et al., 1999; Wang et al., 2000). Paradoxically, we found that the $5-\mathrm{HT}_{2 \mathrm{C}} \mathrm{R}$-mediated neurotransmission is overly sensitized in $V G V$ mice as seen by enhanced response to the $5-\mathrm{HT}_{2 \mathrm{C}} \mathrm{R}$-selective agonists and antagonists. Our radiohistochemical studies indeed revealed that the $5-\mathrm{HT}_{2 \mathrm{C}} \mathrm{R}$-selective agonist binding sites were significantly higher in the entire brain region including choroid plexus, Arc, and PVH of VGV mice compared with wild-type or INI mice. The results indicate clearly the increased expression of functional receptors capable of binding to the agonist, although the overall expression of the $5-\mathrm{HT}_{2 \mathrm{C}} \mathrm{R}$ receptors detected by analysis of their mRNA or protein levels was not so different in $V G V$ mice compared with wild-type or INI mice (supplemental Figs. S2, S3, available at www.jneurosci.org as supplemental material). 
It has been reported that the intracellular trafficking efficacy and cell surface expression of the VGV isoform are significantly higher than those of the INI receptor (Marion et al., 2004). In contrast, most INI receptors are internalized and exist mainly as the desensitized form accumulated in endosomes because of formation of a complex with $\beta$-arrestins (Marion et al., 2004). The increased trafficking as well as reduced desensitization kinetics may contribute to constitutive high expression of the functional VGV receptor on the cell surface, which in turn may overcome its low agonist binding affinity and reduced G-protein coupling efficacy reported previously for this fully edited receptor (Burns et al., 1997; Fitzgerald et al., 1999; Niswender et al., 1999). Although additional studies are required for understanding the precise mechanism that increases the agonist binding sites, oversensitization of the serotonergic neurotransmission observed in $V G V$ mice most likely resulted from the dramatic increase of functional receptor expression on the cell surface.

Our findings highlight the importance of the regulation of $5-H T_{2 C} R$ mRNA editing. Expression of the fully edited VGV isoform receptor is limited to certain brain regions such as the hypothalamus and frontal cortex, whereas other editing isoforms such as VNV or VSV are more commonly detected (Burns et al., 1997; Fitzgerald et al., 1999; Wang et al., 2000). The 5-HT ${ }_{2 C} R$ mRNA editing pattern has been reported to change dynamically in response to stress or medication (Englander et al., 2005). In $V G V$ mice, the spatial and stress or medication-responsive regulation of $5-H T_{2 C} R$ mRNA editing is removed, resulting in exclusive expression of the $V G V$ receptor. Our results clearly demonstrate that dysregulated editing, overediting but not underediting, of 5- $\mathrm{HT}_{2 \mathrm{C}} \mathrm{R}$ mRNA can cause pathological consequences at least for control of energy homeostasis as demonstrated by the inappropriately increased energy expenditure and retarded growth phenotypes of $V G V$ mice. This is in contrast to AMPA glutamate receptor B subunit (GluR-B) Q/R site editing (Higuchi et al., 2000). GluR-B mRNAs are edited at the $\mathrm{Q} / \mathrm{R}$ site almost exclusively by ADAR2, leading to the replacement of the gene-encoded Glu with Arg. In adults, the Q/R site editing efficiency is normally set to almost $100 \%$. In other words, the Q/R site editing is essentially unregulated and produces mostly edited protein. This unregulated and extremely high editing efficiency must be critical, because a slight decrease of the editing efficiency has proven to be pathological, resulting in seizures and premature death in $A D A R 2^{-/-}$mice (Feldmeyer et al., 1999; Higuchi et al., 2000). Thus, too much editing of sites like $5-\mathrm{HT}_{2 \mathrm{C}} \mathrm{R}-\mathrm{VGV}$ can be deleterious, as can too little editing of sites like GluR-B Q/R.

Substantial variations in metabolic rate and obesity detected among individuals of different ages and ethnic backgrounds may be related, at least in part, to differences in editing efficacy of $5-H T_{2 C} R$ mRNAs. It is of special interest to determine whether higher VGV levels are detected in individuals with high metabolic rates. In recent years, $5-\mathrm{HT}_{2 \mathrm{C}} \mathrm{R}$ selective agonists have been used for obesity prevention and treatment (Halford et al., 2005). Our findings suggest that editing of $H T_{2 C} R$ mRNA can be a future target of great promise for development of drugs to control body weight. Finally, dysregulation of $5-H T_{2 C} R$ mRNA editing has been implicated in pathological processes of human mental illness such as suicidal depression and schizophrenia (Niswender et al., 2001; Sodhi et al., 2001; Gurevich et al., 2002). Additional behavioral and pharmacological analyses of $V G V$ and INI mice will provide an invaluable animal model system to evaluate the significance of 5- $\mathrm{HT}_{2 \mathrm{C}} \mathrm{R}$ mRNA editing not only for energy metabolism but also for processes that regulate emotion and behavior as well as human mental disorders.

\section{References}

Bale TL, Davis AM, Auger AP, Dorsa DM, McCarthy MM (2001) CNS region-specific oxytocin receptor expression: importance in regulation of anxiety and sex behavior. J Neurosci 21:2546-2552.

Balthasar N, Dalgaard LT, Lee CE, Yu J, Funahashi H, Williams T, Ferreira M, Tang V, McGovern RA, Kenny CD, Christiansen LM, Edelstein E, Choi B, Boss O, Aschkenasi C, Zhang CY, Mountjoy K, Kishi T, Elmquist JK, Lowell BB (2005) Divergence of melanocortin pathways in the control of food intake and energy expenditure. Cell 123:493-505.

Bass BL (2000) Double-stranded RNA as a template for gene silencing. Cell 101:235-238.

Bouret SG, Draper SJ, Simerly RB (2004) Formation of projection pathways from the arcuate nucleus of the hypothalamus to hypothalamic regions implicated in the neural control of feeding behavior in mice. J Neurosci 24:2797-2805.

Burns CM, Chu H, Rueter SM, Hutchinson LK, Canton H, Sanders-Bush E, Emeson RB (1997) Regulation of serotonin-2C receptor G-protein coupling by RNA editing. Nature 387:303-308.

Di Matteo V, De Blasi A, Di Giulio C, Esposito E (2001) Role of 5-HT(2C) receptors in the control of central dopamine function. Trends Pharmacol Sci 22:229-232.

Englander MT, Dulawa SC, Bhansali P, Schmauss C (2005) How stress and fluoxetine modulate serotonin $2 \mathrm{C}$ receptor pre-mRNA editing. J Neurosci 25:648-651.

Feldmeyer D, Kask K, Brusa R, Kornau HC, Kolhekar R, Rozov A, Burnashev N, Jensen V, Hvalby O, Sprengel R, Seeburg PH (1999) Neurological dysfunctions in mice expressing different levels of the Q/R site-unedited AMPAR subunit GluR-B. Nat Neurosci 2:57-64.

Fitzgerald LW, Iyer G, Conklin DS, Krause CM, Marshall A, Patterson JP, Tran DP, Jonak GJ, Hartig PR (1999) Messenger RNA editing of the human serotonin 5-HT2C receptor. Neuropsychopharmacology 21:82S-90S.

Flomen R, Knight J, Sham P, Kerwin R, Makoff A (2004) Evidence that RNA editing modulates splice site selection in the $5-\mathrm{HT} 2 \mathrm{C}$ receptor gene. $\mathrm{Nu}-$ cleic Acids Res 32:2113-2122.

Greger IH, Khatri L, Ziff EB (2002) RNA editing at arg607 controls AMPA receptor exit from the endoplasmic reticulum. Neuron 34:759-772.

Gurevich I, Tamir H, Arango V, Dwork AJ, Mann JJ, Schmauss C (2002) Altered editing of serotonin $2 \mathrm{C}$ receptor pre-mRNA in the prefrontal cortex of depressed suicide victims. Neuron 34:349-356.

Halford JC, Harrold JA, Lawton CL, Blundell JE (2005) Serotonin (5-HT) drugs: effects on appetite expression and use for the treatment of obesity. Curr Drug Targets 6:201-213.

Heisler LK, Cowley MA, Tecott LH, Fan W, Low MJ, Smart JL, Rubinstein M, Tatro JB, Marcus JN, Holstege H, Lee CE, Cone RD, Elmquist JK (2002) Activation of central melanocortin pathways by fenfluramine. Science 297:609-611.

Heisler LK, Jobst EE, Sutton GM, Zhou L, Borok E, Thornton-Jones Z, Liu HY, Zigman JM, Balthasar N, Kishi T, Lee CE, Aschkenasi CJ, Zhang CY, Yu J, Boss O, Mountjoy KG, Clifton PG, Lowell BB, Friedman JM, Horvath $\mathrm{T}$, et al. (2006) Serotonin reciprocally regulates melanocortin neurons to modulate food intake. Neuron 51:239-249.

Higuchi M, Maas S, Single FN, Hartner J, Rozov A, Burnashev N, Feldmeyer D, Sprengel R, Seeburg PH (2000) Point mutation in an AMPA receptor gene rescues lethality in mice deficient in the RNA-editing enzyme ADAR2. Nature 406:78-81.

Hücking K, Hamilton-Wessler M, Ellmerer M, Bergman RN (2003) Burstlike control of lipolysis by the sympathetic nervous system in vivo. J Clin Invest 111:257-264.

Huszar D, Lynch CA, Fairchild-Huntress V, Dunmore JH, Fang Q, Berkemeier LR, Gu W, Kesterson RA, Boston BA, Cone RD, Smith FJ, Campfield LA, Burn P, Lee F (1997) Targeted disruption of the melanocortin-4 receptor results in obesity in mice. Cell 88:131-141.

Kawahara Y, Zinshteyn B, Sethupathy P, Iizasa H, Hatzigeorgiou AG, Nishikura K (2007a) Redirection of silencing targets by adenosine-toinosine editing of miRNAs. Science 315:1137-1140.

Kawahara Y, Zinshteyn B, Chendrimada TP, Shiekhattar R, Nishikura K (2007b) RNA editing of the microRNA-151 precursor blocks cleavage by the Dicer-TRBP complex. EMBO Rep 8:763-769.

Kawahara Y, Megraw M, Kreider E, Iizasa H, Valente L, Hatzigeorgiou AG, Nishikura K (2008) Frequency and fate of microRNA editing in human brain. Nucleic Acids Res 36:5270-5280.

Lam DD, Przydzial MJ, Ridley SH, Yeo GS, Rochford JJ, O’Rahilly S, Heisler 
LK (2008) Serotonin 5-HT2C receptor agonist promotes hypophagia via downstream activation of melanocortin 4 receptors. Endocrinology 149:1323-1328.

Lindqvist A, de la Cour CD, Håkanson R, Erlanson-Albertsson C (2007) Ghrelin affects gastrectomy-induced decrease in UCP1 and beta(3)-AR mRNA expression in mice. Regul Pept 142:24-28.

López-Giménez JF, Tecott LH, Palacios JM, Mengod G, Vilaró MT (2002) Serotonin 5- HT (2C) receptor knockout mice: autoradiographic analysis of multiple serotonin receptors. J Neurosci Res 67:69-85.

Lowell BB, Bachman ES (2003) Beta-Adrenergic receptors, diet-induced thermogenesis, and obesity. J Biol Chem 278:29385-29388.

Lucki I, Ward HR, Frazer A (1989) Effect of 1-(m-chlorophenyl)piperazine and 1-(m-trifluoromethylphenyl)piperazine on locomotor activity. J Pharmacol Exp Ther 249:155-164.

Marion S, Weiner DM, Caron MG (2004) RNA editing induces variation in desensitization and trafficking of 5-hydroxytryptamine $2 \mathrm{c}$ receptor isoforms. J Biol Chem 279:2945-2954

Nakamura K, Morrison SF (2007) Central efferent pathways mediating skin cooling-evoked sympathetic thermogenesis in brown adipose tissue. Am Physiol Regul Integr Comp Physiol 292:R127-R136.

Nishikura K (2006) Editor meets silencer: crosstalk between editing and RNA interference. Nat Rev Mol Cell Biol 7:919-931.

Niswender CM, Copeland SC, Herrick-Davis K, Emeson RB, Sanders-Bush E (1999) RNA editing of the human serotonin 5-hydroxytryptamine 2C receptor silences constitutive activity. J Biol Chem 274:9472-9478

Niswender CM, Herrick-Davis K, Dilley GE, Meltzer HY, Overholser JC, Stockmeier CA, Emeson RB, Sanders-Bush E (2001) RNA editing of the human serotonin 5-HT2C receptor: alterations in suicide and implications for serotonergic pharmacotherapy. Neuropsychopharmacology 24:478-491.

Nonogaki K, Abdallah L, Goulding EH, Bonasera SJ, Tecott LH (2003) Hyperactivity and reduced energy cost of physical activity in serotonin 5-HT(2C) receptor mutant mice. Diabetes 52:315-320.

Ohlson J, Pedersen JS, Haussler D, Ohman M (2007) Editing modifies the GABA(A) receptor subunit alpha3. RNA 13:698-703.

Plagge A, Gordon E, Dean W, Boiani R, Cinti S, Peters J, Kelsey G (2004) The imprinted signaling protein XL alpha $\mathrm{s}$ is required for postnatal adaptation to feeding. Nat Genet 36:818-826.

Ralph RJ, Paulus MP, Fumagalli F, Caron MG, Geyer MA (2001) Prepulse inhibition deficits and perseverative motor patterns in dopamine transporter knock-out mice: differential effects of $\mathrm{D}_{1}$ and $\mathrm{D}_{2}$ receptor antagonists. J Neurosci 21:305-313.

Reenan RA (2001) The RNA world meets behavior: A $\rightarrow$ I pre-mRNA editing in animals. Trends Genet 17:53-56.

Richer M, Hen R, Blier P (2002) Modification of serotonin neuron properties in mice lacking 5-HT1A receptors. Eur J Pharmacol 435:195-203.

Rula EY, Lagrange AH, Jacobs MM, Hu N, Macdonald RL, Emeson RB (2008) Developmental modulation of $\mathrm{GABA}_{\mathrm{A}}$ receptor function by RNA editing. J Neurosci 28:6196-6201.

Seeburg PH, Hartner J (2003) Regulation of ion channel/neurotransmitter receptor function by RNA editing. Curr Opin Neurobiol 13:279-283.

Sodhi MS, Burnet PW, Makoff AJ, Kerwin RW, Harrison PJ (2001) RNA editing of the 5-HT(2C) receptor is reduced in schizophrenia. Mol Psychiatry 6:373-379.

Stark JA, Davies KE, Williams SR, Luckman SM (2006) Functional magnetic resonance imaging and c-Fos mapping in rats following an anorectic dose of m-chlorophenylpiperazine. Neuroimage 31:1228-1237.

Tecott LH, Sun LM, Akana SF, Strack AM, Lowenstein DH, Dallman MF, Julius D (1995) Eating disorder and epilepsy in mice lacking 5-HT2c serotonin receptors. Nature 374:542-546.

Wang Q, O'Brien PJ, Chen CX, Cho DS, Murray JM, Nishikura K (2000) Altered G protein-coupling functions of RNA editing isoform and splicing variant serotonin $2 \mathrm{C}$ receptors. J Neurochem 74:1290-1300.

Xie T, Plagge A, Gavrilova O, Pack S, Jou W, Lai EW, Frontera M, Kelsey G, Weinstein LS (2006) The alternative stimulatory G protein alpha-subunit XLalphas is a critical regulator of energy and glucose metabolism and sympathetic nerve activity in adult mice. J Biol Chem 281:18989-18999.

Yang W, Chendrimada TP, Wang Q, Higuchi M, Seeburg PH, Shiekhattar R, Nishikura K (2006) Modulation of microRNA processing and expression through RNA editing by ADAR deaminases. Nat Struct Mol Biol 13:13-21.

Zhou L, Sutton GM, Rochford JJ, Semple RK, Lam DD, Oksanen LJ, Thornton-Jones ZD, Clifton PG, Yueh CY, Evans ML, McCrimmon RJ, Elmquist JK, Butler AA, Heisler LK (2007) Serotonin 2C receptor agonists improve type 2 diabetes via melanocortin-4 receptor signaling pathways. Cell Metab 6:398-405. 